\title{
Article
}

\section{Evaluation of the genotoxic and physiological effects of decabromodiphenyl ether (BDE-209) and dechlorane plus (DP) flame retardants in marine mussels (Mytilus galloprovincialis)}

Enrique Barón, Awantha Dissanayake, Judit Vila, Charlotte Crowther, James W. Readman, Awadhesh Jha, Ethel Eljarrat, and Damia Barcelo

Environ. Sci. Technol., Just Accepted Manuscript • DOI: 10.1021/acs.est.5b05814 • Publication Date (Web): 01 Feb 2016 Downloaded from http://pubs.acs.org on February 4, 2016

\section{Just Accepted}

"Just Accepted" manuscripts have been peer-reviewed and accepted for publication. They are posted online prior to technical editing, formatting for publication and author proofing. The American Chemical Society provides "Just Accepted" as a free service to the research community to expedite the dissemination of scientific material as soon as possible after acceptance. "Just Accepted" manuscripts appear in full in PDF format accompanied by an HTML abstract. "Just Accepted" manuscripts have been fully peer reviewed, but should not be considered the official version of record. They are accessible to all readers and citable by the Digital Object Identifier (DOI®). "Just Accepted" is an optional service offered to authors. Therefore, the "Just Accepted" Web site may not include all articles that will be published in the journal. After a manuscript is technically edited and formatted, it will be removed from the "Just Accepted" Web site and published as an ASAP article. Note that technical editing may introduce minor changes to the manuscript text and/or graphics which could affect content, and all legal disclaimers and ethical guidelines that apply to the journal pertain. ACS cannot be held responsible for errors or consequences arising from the use of information contained in these "Just Accepted" manuscripts. 


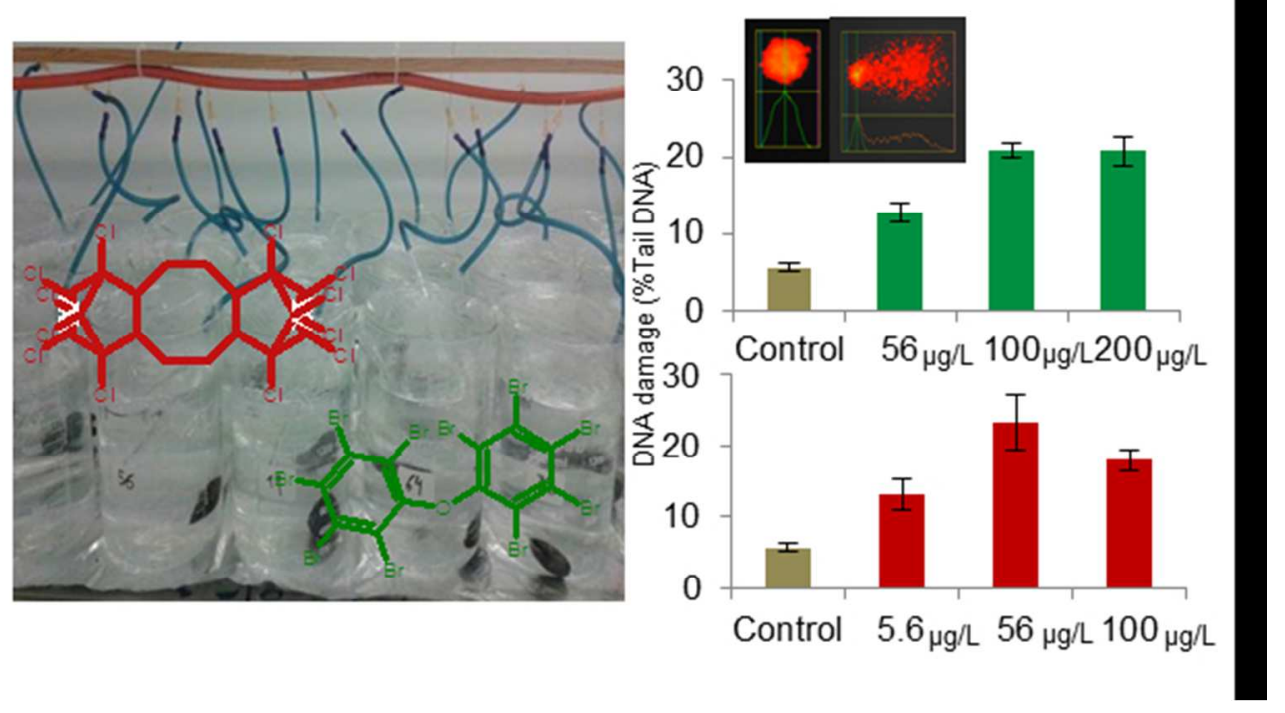

$106 \times 59 \mathrm{~mm}(150 \times 150 \mathrm{DPI})$ 
1 Evaluation of the genotoxic and physiological effects of

2 decabromodiphenyl ether (BDE-209) and dechlorane plus (DP) flame

3 retardants in marine mussels (Mytilus galloprovincialis)

4 Barón, E. ${ }^{1}$, Dissanayake, A. ${ }^{2}$, Vila, J. ${ }^{1}$, Crowther, C. ${ }^{2}$, Readman, J.W. ${ }^{2,3,4}$, Jha, A. ${ }^{2}$,

5 Eljarrat, E. ${ }^{1 *}$, Barceló, D. ${ }^{1,5}$

6

7 1) Institute of Environmental Assessment and Water Research Studies (IDAEA),

8 Spanish Council for Scientific Research (CSIC), Jordi Girona 18-26, 08034 Barcelona,

9 Spain.

10 2) Plymouth University, School of Biological Sciences, Drake Circus, Plymouth

11 University, PL4 8AA, U.K

12 3) Plymouth University, School of Geography, Earth \& Environmental Sciences, Drake

13 Circus, Plymouth University, PL4 8AA, U.K

14 4) Plymouth Marine Laboratory, Prospect Place, The Hoe, Plymouth, PL1 3DH, U.K

15 5) Catalan Institute for Water Research (ICRA), H2O Building, Scientific and

16 technological Park of the University of Girona, Emili Grahit 101, 17003 Girona, Spain. 


\section{Abstract}

18 Dechlorane plus (DP) is a proposed alternative to the legacy flame retardant

19 Decabromodiphenyl ether (BDE-209), a major component of Deca-BDE formulations.

20 In contrast to BDE-209, toxicity data for DP are scarce and often focused in mice.

21 Validated dietary in vivo exposure of the marine bivalve (Mytilus galloprovincialis) to

22 both flame retardants did not induce effects at the physiological level (algal clearance

23 rate), but induced oxidative DNA damage, as determined by the comet assay, at all the

24 concentrations tested. Micronuclei formation was induced by both DP and BDE-209 at

25 the highest exposure concentrations (100 and $200 \mu \mathrm{g} / \mathrm{L}$, respectively, at $18 \%$ above

26 controls). DP caused similar effects to BDE-209 but at lower exposure concentrations

27 (5.6, 56 and $100 \mu \mathrm{g} / \mathrm{L}$ for DP and 56, 100 and $200 \mu \mathrm{g} / \mathrm{L}$ for BDE-209). Moreover,

28 bioaccumulation of DP was shown to be concentration dependent, in contrast to BDE-

29 209. The results described suggest that DP poses a greater genotoxic potential than

$30 \quad$ BDE-209. 


\section{Introduction}

32 Polybrominated diphenyl ethers (PBDEs) were one of the most used halogenated flame

33 retardants (HFRs) worldwide, available as three main commercial mixtures: Penta-

34 BDE, Octa-BDE and Deca-BDE. ${ }^{1}$ However, this situation has changed due to recent

35 restrictions over PBDEs. Within the European Union (EU), Penta- and Octa-BDE

36 mixtures were banned in 2004, while Deca-BDE mixture was banned in $2008 .^{2}$ PBDEs

37 have been found in a wide range of environmental matrices such as sediment, water,

38 fish or cetaceans, and also in humans. ${ }^{3-8}$ Nonetheless, environmental behavior and

39 effects of BDE-209 have been studied to a lesser extent to those of lower brominated

40 PBDEs. This might be due to the limitations in the analytical methodologies for the

41 analysis of this compound in the past, due to its high $\log \mathrm{K}_{\mathrm{ow}}$ and molecular weight. ${ }^{9}$

42 Despite the bioaccumulation potential being lower than other low brominated PBDEs

43 such as BDE-47, BDE-209 has been found in different vertebrate and invertebrate

44 species worldwide. ${ }^{2,10,11}$ In fact, BDE-209 was the main PBDE found in species with

45 terrestrial diet ${ }^{2,10,12}$ and also in mussels. ${ }^{11,13}$ BDE-209 has shown thyroid and endocrine

46 disruption properties ${ }^{14,15}$ and it could affect the liver of fish and mice. ${ }^{15,16}$ Most of the

47 studies are focused in vertebrate models such fish or mice, ${ }^{17}$ thus studies in invertebrates

48 such as mussels are scarce.

49 Dechlorane plus (DP) was selected as an alternative to Mirex when it was banned as a

$50 \mathrm{FR}$, and currently it has been proposed as an alternative to the Deca-BDE mixture. It is

51 considered a novel HFR and is still barely regulated. ${ }^{18-20}$ Similar to BDE-209, DP has

52 been found a wide range of biological matrices such as fish, mussels or cetaceans and

53 also in humans, showing its bioaccumulation capacity. ${ }^{18-21}$ Toxicity data for DP are still

54 very scarce. ${ }^{22,} 23$ In fish, DP affected protein responses in the liver and induced 
55 apoptosis, ${ }^{24}$ while it showed genotoxical potential in bacteria ${ }^{22}$ as well as

56 histopathological changes in mice liver. ${ }^{25}$

57 Mussels have proven to be a good tool to evaluate the environmental behavior of

58 organic pollutants. ${ }^{26}$ Furthermore, effects of organic pollutants in mussels have been

59 correlated with effects of the same pollutants in humans ${ }^{27}$ which shows that these

60 contaminants can affect the whole food chain. Thus, the study of the effects of FRs in

61 mussels could provide useful information concerning the potential for effects of these

62 contaminants in other biota and ecosystems. Consequently, the aim of this study was to

63 evaluate the genotoxic and physiological effects of one classical FR (BDE-209, which

64 represents about the $98 \%$ of Deca-BDE commercial mixture) and one alternative FR

65 commercial mixture (DP) in Mytilus galloprovincialis through an in vivo exposure via

66 the dietary pathway. To our knowledge, this is the first time that the toxicity of DP has

67 been evaluated in this way. Mytilus galloprovincialis is predominately native to the

68 Mediterranean coast and the Black and Adriatic Seas, however, has established itself as

69 a global invader. This species has highly conserved gene sequences shared by higher

70 organisms including humans as described by us in previous studies. ${ }^{28}$ Effects reported in

71 this model invertebrate would therefore have significance for higher-level impacts in

72 coastal environments and could be translated to other species.

74 Materials and methods

\section{Sample collection}

76 M. galloprovincialis (5-6 cm length) were collected during the last week of July 2014

77 from Trebarwith Strand (North Cornwall, UK), one of the most pristine sites in the UK,

78 and were immediately transported to the laboratory, rinsed with sea water and

79 acclimatised in an aerated tank with $50 \mathrm{~L}$ of filtered seawater $(0.8 \mu \mathrm{m})$, where they were 
80 maintained at $15{ }^{\circ} \mathrm{C} \pm 1{ }^{\circ} \mathrm{C}$ with a photoperiod of $12 \mathrm{~h}$ Light: $12 \mathrm{~h}$ Darkness for 10 days

81 and fed every two days with Isochrysis galbana (Liquifry, Interpet, Dorking, UK).

82 Stocking density was 3 mussels per L. Water was changed 2-3 hours after feeding. Any

83 spawning animals were removed from the holding conditions and no animals spawned

84 during the experiments.

85

86 Chemicals and reagents

87 Triton X-100, Sodium chloride, Normal Melting point Agarose (NMPA), Low melting 88 point agarose (LMPA) and N-lauryl sarcosine were purchased from Sigma-Aldrich 89 (UK). BFR-PAR solution, containing BDE-28, BDE-47, BDE-99, BDE-100, BDE-154, 90 BDE-183 and BDE-209, together with syn- and anti- DP were purchased from 91 Wellington Laboratories (Guelph, ON, Canada), as well as the internal standard ${ }^{13} \mathrm{C}$ -

92 BDE-209. ${ }^{13}$ C-syn-DP, used also as internal standard, was obtained from Cambridge 93 Isotope Laboratories (Andover, MA).

95 Experiment

96 To assess whether the feeding route was a valid exposure pathway for filter-feeding 97 organisms when exposed to high $\log \mathrm{K}_{\mathrm{ow}}$ organic contaminants, a preliminary 98 experiment using benzo(a)pyrene $(\mathrm{B}(\alpha) \mathrm{P})$ was performed. Genotoxic potential of this 99 polycyclic aromatic hydrocarbon $(\mathrm{PAH})$ is well known and it is often used as genotoxic

100 model. $^{28}$ Individual mussels were placed in $2 \mathrm{~L}$ beakers containing $1.8 \mathrm{~L}$ of filtered 101 seawater and exposed to $\mathrm{B}(\alpha) \mathrm{P}$ at either 100 or $200 \mu g \mathrm{~L}^{-1}$ for six days, each 102 concentration dosed either by spiking algae Isochrysis galbana or directly into the 103 aqueous media ( $\mathrm{n}=6$ per concentration treatment, including a solvent carrier (acetone, $1040.05 \% \mathrm{v} / \mathrm{v}$ ) control with only acetone). Both exposure pathways were conducted 
105 following a semi-static model where water was changed every day and mussels fed 106 daily. $\mathrm{B}(\alpha) \mathrm{P}$ was chosen as a model organic contaminant as it is relatively insoluble in 107 water $\left(\log \mathrm{K}_{\mathrm{OW}}=6.04\right)$, is known to cause genetic damage and is a priority pollutant. ${ }^{28}$

108 After the dietary pathway proved to be a valid exposure route, mussels were exposed to 109 three different concentrations of BDE-209 (56, 100 and $\left.200 \mu \mathrm{gL}^{-1}\right)$ and DP $(5.6,56$ and

$110100 \mu \mathrm{gL}^{-1}$ ), following the procedure described above, i.e. individual mussels ( $\mathrm{n}=7$ for 111 each concentration treatment) were placed in $2 \mathrm{~L}$ beakers containing $1.8 \mathrm{~L}$ of filtered 112 seawater. Algae mortality was evaluated before the first exposure by exposing an 113 aliquot of the algae to seawater, acetone, acetone + DP and acetone + BDE-209. No

114 changes in cell size were observed. Concentrations of DP found in the environment and 115 specifically in mussels are considerably lower than concentrations found for BDE-209.

116 Thus, exposure concentrations of DP were settled in lower scale, although 2 common 117 concentrations were maintained for comparisons. Environmental concentrations of these 118 contaminants in mussels depend in a great extent on the sampling area. For instance, DP 119 has been found at levels up to $190 \mathrm{ng} / \mathrm{g} \mathrm{lw}$ (lipid weight) in an industrial area of China, 120 but concentrations in rural areas were considerably lower, $4.1 \mathrm{ng} / \mathrm{g} \mathrm{lw}{ }^{29,}{ }^{30}$ These 121 concentrations are of the same magnitude (parts per billion, ppb) as concentrations 122 selected in this study. Concerning BDE-209, concentrations reported worldwide vary 123 substantially. BDE-209 has been reported at concentrations up to $812 \mathrm{ng} / \mathrm{g} \mathrm{dw}$ in 124 sediments $^{31}$ and it is detected consistently in wild mussels. ${ }^{32}$ Hence, it is present at 125 important levels in the environment and bioconcentrates. The selected exposure 126 concentrations are higher than some reported globally, but are in the same order as 127 others. $\mathrm{A} \mathrm{B}(\alpha) \mathrm{P}$ exposure at $100 \mu \mathrm{gL}^{-1}$ as positive in vivo control together with a 128 negative control (acetone, $0.05 \%$, v/v final volume) were also performed ( $\mathrm{n}=7$ per 
129 treatment). $\mathrm{H}_{2} \mathrm{O}_{2}$ was also used as positive in vitro control (1 $\mathrm{mM}$ and $30 \mathrm{~min}$ of 130 exposure time).

131 In both experiments, after the six days of exposure mussel haemolymph was extracted

132 from the posterior adductor muscle using an ice-chilled $1 \mathrm{~mL}$ syringe and $21 \mathrm{G}$ needle 133 and transferred into individual Eppendorf tubes held on ice, following the protocol 134 described by Brown et al. (2004). ${ }^{33}$

\section{Water quality}

137 Water quality (temperature, salinity, dissolved oxygen and $\mathrm{pH}$ ) was measured every day

138 for each beaker and three water samples of each treatment were taken immediately after 139 dosing and prior to water change (i.e after $23 \mathrm{~h}$ of exposure).

140 Water temperature during the exposure was $16.0 \pm 0.5^{\circ} \mathrm{C}$, salinity was $36.3 \pm 0.2 \%$,

141 dissolved oxygen was $7.93 \pm 0.2 \mathrm{mg} / \mathrm{L}$, and $\mathrm{pH}$ was $7.92 \pm 0.08$. No intra- or inter-day 142 variations among treatments were observed (ANOVA and post-hoc Tukey's test) and 143 these values were considered optimal for the exposures.

Clearance rate

146 Clearance rate $(\mathrm{CR})$ was determined prior to haemolymph collection as described

147 previously. ${ }^{34}$ Mussels were placed in separate $400 \mathrm{~mL}$ beakers containing $350 \mathrm{~mL}$ 148 seawater (filtered to $0.8 \mu \mathrm{m}$ ) and a stirring bar. They were allowed to acclimatise at 15

$149{ }^{\circ} \mathrm{C}$ for 15 min. Isochrysis galbana was added in a concentration of 10,000 cells $/ \mathrm{mL}$, 150 including several procedural blanks (beaker plus $300 \mathrm{~mL}$ of seawater). Aliquots of 20 $151 \mathrm{~mL}$ were removed immediately after the addition and after 10, 20 and 30 minutes. These 152 aliquots were analysed on a Beckman Coulter Particle Size and Count Analyser set to 153 count particles between 4 and $10 \mu \mathrm{m}$. Three separate counts per mussel were made. CR 
154 was calculated using the equation $\mathrm{CR}=\mathrm{V}\left(\log \mathrm{C}_{1}-\log \mathrm{C}_{2}\right) / \mathrm{t}$, where $\mathrm{V}$ is the volume of

155 water, $\mathrm{C}_{1}$ and $\mathrm{C}_{2}$ are the cell concentrations at the beginning and end of each increment,

156 and $t$ corresponds to the time interval. ${ }^{35}$

157

Comet assay

159 Determination of DNA strand breaks using haemocytes was evaluated following a

160 previously optimized protocol. ${ }^{36,37}$ Slides were pre-coated with normal melting point

161 (NMP) agarose and kept overnight at $20{ }^{\circ} \mathrm{C}$ to dry. $150 \mu \mathrm{L}$ of haemolymph were

162 centrifuged at $\sim 350 \mathrm{~g}$ at $4{ }^{\circ} \mathrm{C}$ for 2 min and then mixed with $150 \mu \mathrm{L}$ of molten low

163 melting point (LMP) agarose. Two separate drops of $75 \mu \mathrm{L}$ were placed on the slide and

164 immediately covered with a coverslip. Prior to performing the comet assay, cell viability

165 was determined using Eosin Y staining, ${ }^{38}$ viability was deemed $>95 \%$. Slides were kept

166 at $4{ }^{\circ} \mathrm{C}$ and in the dark for one hour to allow the gel to solidify. In the case of the $\mathrm{H}_{2} \mathrm{O}_{2}$

167 in vitro positive control, after one hour $1 \mathrm{~mL}$ of $\mathrm{H}_{2} \mathrm{O}_{2}(1 \mathrm{mM})$ was added dropwise and

168 incubated at $4^{\circ} \mathrm{C}$ for $30 \mathrm{~min}$. Slides were incubated in lysis solution for one hour and in

169 the dark at $4{ }^{\circ} \mathrm{C}$, placed in the electrophoresis chamber, filled with electrophoresis

170 buffer, and incubated for 20 min to unwind. Afterwards, the chamber was turned on (25

$171 \mathrm{~V}, 400 \mathrm{~mA}$ ) and electrophoresis performed for $20 \mathrm{~min}$. Following on, slides were

172 neutralised with cold neutralization buffer. All the steps in the electrophoresis procedure

173 were performed at $4{ }^{\circ} \mathrm{C}$ and in the dark. Slides were stained with ethidium bromide (20

$174 \mu \mathrm{L}$ of a $20 \mu \mathrm{g} / \mathrm{mL}$ solution in each drop) and scored under an epifluorescense

175 microscope (Leica, DMR) using the Komet 5 software (Kinetic Imaging, Nothingam).

17650 cells in each drop, thus a total of 100 cells per slide, were scored and \% tail DNA

177 was used for the evaluation of DNA strand breaks, since it has been validated through

178 inter-laboratory comparisons. ${ }^{39,}{ }^{40}$ In total, 7 slides per treatment for a total number of 
17963 slides (3 DP treatments, 3 BDE-209 treatments, $1 \mathrm{~B}(\alpha) \mathrm{P}$ treatment, 1 negative

180 control and $1 \mathrm{H}_{2} \mathrm{O}_{2}$ treatment) were analysed. Abnormal comets were excluded from the

181 scoring following the criteria proposed previously. ${ }^{41}$ In short, cells outside the gel,

182 double cells or comets in contact with other comets were not scored, and only comets

183 with one round head on the back most side in the direction of the analysis were scored.

185 Mn assay

186 Induction of micronuclei (Mn) in haemocytes was evaluated as described by Jha et al. ${ }^{37}$

187 Slides were previously coated with $10 \%$ poly-L-lysine solution and dried overnight. 200

$188 \mu \mathrm{L}$ of haemolymph was spread gently onto the slide and left at $15{ }^{\circ} \mathrm{C}$ for $30 \mathrm{~min}$ and

189 then fixed with $\mathrm{MeOH}$ for 15 min. Afterwards, slides were stained using Giemsa stain

$190(5 \%, v / v)$ for $20 \mathrm{~min}$; excess stain was removed with Milli-Q water and once the slides

191 were air dried, a coverslip was mounted using DPX. Slides were scored randomly under

192 the microscope for the induction of Mn. Approximately 1000 cells from each slide were

193 scored following the criteria described in previous works. ${ }^{37}$ In total, 63 slides (7 per

194 treatment) were analysed. Only agranular cells were scored, and apoptotic and necrotic

195 haemocytes were excluded from the analysis. Moreover, haemocytes with induced MN

196 were carefully distinguished from haemocytes with nuclear buds; the latter were not

197 counted. $^{42}$

198

\section{Chemical analysis}

200 Regarding water and algae analysis, the methodology described by $\mathrm{Di}$ et al. was

201 adopted. $^{28}$ Hexane $(1 \mathrm{~mL})$ was added to $9 \mathrm{~mL}$ of the exposure water samples and

202 internal standards $\left({ }^{13} \mathrm{C}\right.$-BDE-209 and ${ }^{13} \mathrm{C}$-syn-DP) were added. Samples were manually

203 shaken and then centrifuged at $3500 \mathrm{rpm}$ for $10 \mathrm{~min}$. The aqueous phase was discarded 
204 and the organic phase was evaporated to dryness and was reconstituted to a final volume 205 of $500 \mu \mathrm{L}$ with toluene.

206 Mussel samples were extracted using a previously described methodology. ${ }^{43,44}$ Briefly, 207 samples were spiked with 100 ng of ${ }^{13} \mathrm{C}$-BDE-209 and ${ }^{13} \mathrm{C}$-syn-DP and kept overnight 208 to equilibrate prior to extraction by pressurized liquid extraction (PLE). Afterwards, 209 lipid content was determined gravimetrically and re-dissolved in hexane prior to acid 210 treatment $\left(\mathrm{H}_{2} \mathrm{SO}_{4(\mathrm{c})}\right)$. A solid phase extraction (SPE) using Al-N cartridges (Biotage, $5 \mathrm{~g}$ 211 and $20 \mathrm{~mL}$ ) was performed to complete the clean-up and resulting extracts were 212 concentrated to a final volume of $40 \mu \mathrm{L}$.

213 Instrumental analysis was carried out using gas chromatography coupled to mass 214 spectrometry working in negative chemical ionization mode (GC-NCI-MS) using an 215 Agilent Technologies 7890A GC system coupled to 5890A GC/MS Single Quadrupole, 216 following previously optimized protocols. ${ }^{45,}{ }^{46}$ BDE-209 was analysed using $\mathrm{NH}_{3}$ as 217 reagent gas, whereas DP was analysed using $\mathrm{CH}_{4}$ as reagent gas. Selected ion 218 monitoring (SIM) was used to enhance sensitivity. Two ions were monitored for each 219 compound: the most intense was used for quantification and the second for 220 confirmation. Ions monitored were $m / z 487$ and 489 for BDE-209 (497 and 499 for ${ }^{13} \mathrm{C}$ 221 BDE-209) and $m / z 654$ and 656 for DP (664 and 666 for ${ }^{13} \mathrm{C}$-syn-DP). Recoveries, 222 method detection limits (MDLs) and method quantification limits (MQLs) are shown in 223 Table 1. Recoveries were determined by spiking $1 \mathrm{~g}$ of individual mussel samples with $22410 \mathrm{ng}$ of syn- and anti-DP and $50 \mathrm{ng}$ of BDE-209. Five replicates were made, together 225 with 3 blank samples. MDLs and MQLs were determined as the concentrations which 226 gave a signal to noise ratio $(\mathrm{S} / \mathrm{N})$ of 3 and 10 , respectively. 
229 Data were tested for normality and homogeneity of variances using the Shapiro-Wilks

230 test of normality and an F test. Statistical significance between different treatments was

231 determined using analysis of variance (ANOVA), post-hoc Tukey's test and t-test; a $p$

232 value $\leq 0.05$ was used to determine significant differences. Statistical analyses were

233 conducted using the open-source statistical programming language $\mathrm{R}$ v.3.1.1

234 (http://cran.r-project.org).

235

236 Results and discussion

$237 \mathrm{H}_{2} \mathrm{O}_{2}$ in vitro control validation

238 Various concentrations $(0.2,0.5$ and $1 \mathrm{mM})$ and time points $(10$ and $30 \mathrm{~min})$ were

239 explored in order to validate $\mathrm{H}_{2} \mathrm{O}_{2}$ doses to promote DNA damage. Results show that

240 DNA damage due to $\mathrm{H}_{2} \mathrm{O}_{2}$ exposure in vitro is time-dependant with significantly more

241 DNA damage apparent at the longer time point (ANOVA, $p<0.001$ ). Based on these

242 data, both in the pathway validation and in the main experiment in vitro controls were

243 performed using a concentration of $1 \mathrm{mM}$ and $30 \mathrm{~min}$ of exposure time.

245 Dietary pathway validation

246 DNA damage was observed in all $\mathrm{B}(\alpha) \mathrm{P}$-exposed mussels, irrespective of exposure 247 route (diet or aqueous), and was significantly different from control mussels (ANOVA, $248 p<0.001)$, (Fig. 1). The solvent control exhibited a small amount of DNA damage $(<10$ $249 \%)$ and DNA damage levels of $\mathrm{B}(\alpha) \mathrm{P}$ were similar in all $\mathrm{B}(\alpha) \mathrm{P}$-exposed mussels $(c a .30$ $250 \pm 6 \%$, mean \pm standard deviation), approximately $20 \%$ higher than in controls. DNA

251 damage observed in the positive in vitro control, $\mathrm{H}_{2} \mathrm{O}_{2}$, was fivefold greater than 252 observed in the controls (at $50 \pm 9 \%$ ). DNA damage was not concentration-dependent. 253 Results showed that the dietary pathway and the direct aqueous exposure did not affect 
254 the results. $\mathrm{B}(\alpha) \mathrm{P}$ is a known genotoxin and our results are in agreement with previous

255 studies. $^{28,47,48}$ For instance, Di et al. report $60 \%$ damage following a 12 days in vivo 256 exposure Mytilus edulis. ${ }^{28}$ However, DNA strand breaks in control mussels were $30 \%$ 257 and thus, DNA relative damage induced by $\mathrm{B}(\alpha) \mathrm{P}$ was up to $30 \%$, similar to our 258 reported values.

259

260 Clearance rate

261 It has been previously demonstrated that CR in mussels can be affected by several 262 chemical contaminants. ${ }^{34}$ In this experiment, CR ranged from 0.49 to $0.90 \mathrm{~L} / \mathrm{h}$ in the 263 first time increment $(10 \mathrm{~min})$ both for BDE-209 and DP, while it was 0.46 and $0.69 \mathrm{~L} / \mathrm{h}$ 264 for $\mathrm{B}(\alpha) \mathrm{P}$ and control treatments, respectively. No statistical differences were found 265 among the treatments, although all of them were significantly different than the 266 seawater control (ANOVA, $\mathrm{F}_{2.78}=3.196, p<0.05$ ). The same scenario occurred in the 267 second time increment (20 min), where the CR value increased to 1.64-2.16 for BDE268209 and DP, to 1.29 for $\mathrm{B}(\alpha) \mathrm{P}$ and to 1.57 in controls. Even though values for BDE-209 $269(100 \mu \mathrm{g} / \mathrm{L})$ and DP $(56 \mu \mathrm{g} / \mathrm{L})$ increased faster than other treatments, differences were 270 not significant with any treatment with FR. Finally, after 30 min CR reached values 271 ranging from 1.98 to $2.92 \mathrm{~L} / \mathrm{h}$ both for BDE-209 and DP, $1.77 \mathrm{~L} / \mathrm{h}$ for $\mathrm{B}(\alpha) \mathrm{P}$ and 2.09

272 for control mussels. Again, even if BDE-209 $(100 \mu \mathrm{g} / \mathrm{L})$ and DP $(56 \mu \mathrm{g} / \mathrm{L})$ showed

273 higher values than the other treatments, these differences were not significant (Figure 274 2). Thus, we can summarize that mussels are not significantly affected by these FRs at a 275 physiological level, at least with the endpoint chosen in this study. This fact was 276 described for $\mathrm{B}(\alpha) \mathrm{P}$ in a similar experiment ${ }^{28}$ and suggests that mussels can take up 277 these types of compounds without showing significant physiological changes. ${ }^{38}$ 278 
280 In all cases, DNA strand breaks observed were significantly higher than the negative 281 control (ANOVA and Tukey's test, $p<0.001$ ) (Figure 3). In vivo positive control, $282 \mathrm{~B}(\alpha) \mathrm{P}$, caused an effect of $35 \pm 6 \%$ (mean $\%$ tail $\pm \mathrm{SD}$ ), while the in vitro positive 283 control, $\mathrm{H}_{2} \mathrm{O}_{2}$, resulted in $56 \pm 10 \%$. Damage induced by BDE-209 was $13 \pm 3 \%, 21 \pm$ $2843 \%$ and $21 \pm 6 \%$ for 56,100 and $200 \mu \mathrm{g} / \mathrm{L}$ exposure concentrations, respectively. 285 Damage induced by DP was $13 \pm 4 \%, 23 \pm 3 \%$ and $18 \pm 6 \%$ for $5.6,56$ and $100 \mu \mathrm{g} / \mathrm{L}$ 286 exposure concentrations, respectively. For BDE-209, DNA damage displayed a 287 significant increase from 56 to $100 \mu \mathrm{g} / \mathrm{L}$ treatments, but no increase was observed from 288100 to $200 \mu \mathrm{g} / \mathrm{L}$ treatments. Concerning DP, DNA damage induced by the $56 \mu \mathrm{g} / \mathrm{L}$ was 289 higher than the $5.6 \mu \mathrm{g} / \mathrm{L}$ treatment. However, damage induced by the highest 290 concentration $(100 \mu \mathrm{g} / \mathrm{L})$ was less than that induced by $56 \mu \mathrm{g} / \mathrm{L}$. It has been described 291 that DNA repair mechanisms can affect the response of the mussels to organic 292 contaminants, since the simple breaks mainly produced by these compounds might be 293 repaired by base excision (BER). ${ }^{49}$ Furthermore, reduction of the DNA damage in the 294 most concentrated treatments could be caused by the exclusion of the apoptotic cells of 295 the cell count. ${ }^{50}$ Comparison between BDE-209 and DP exposures at 56 and $100 \mu \mathrm{g} / \mathrm{L}$ 296 showed that DP at $56 \mu \mathrm{g} / \mathrm{L}$ induced oxidative damage at the same level as BDE-209 at $297100 \mu \mathrm{g} / \mathrm{L}(23 \%$ and $21 \%$, respectively), while DNA strand breaks induced by BDE-209 298 at $56 \mu \mathrm{g} / \mathrm{L}$ were in the same level as the low level of DP (13\% and $13 \%$, respectively). 299 Surprisingly, oxidative damage induced by DP at $100 \mu \mathrm{g} / \mathrm{L}(18 \%)$ was lower than at 56 $300 \mu \mathrm{g} / \mathrm{L}$ (or following BDE-209 exposure at 100 and $200 \mu \mathrm{g} / \mathrm{L}$ ) (Figure 3). This difference 301 might be attributed to possible differences in BDE-209 and DP metabolization. In 302 contrast, de-bromination products of BDE-209 are often more toxic than parent BDE$303209 .{ }^{52}$ Furthermore, BDE-209 presents a more complex metabolism since low- 
304 brominated OH-PBDEs could also be formed. ${ }^{53}$ However, this has not been studied in

305 mussels and the \% of PBDEs metabolized to OH-PBDEs seems to be low even in 306 mammals. $^{54-56}$

307 Hence, results presented demonstrate that BDE-209 and DP can both induce DNA 308 strand breaks in mussels. This is in agreement with what previously reported effects in 309 zebra mussel (Dreissena polymorpha) where, similar to this study, BDE-209 caused 310 non-dose dependant DNA damage after an in vivo exposure of 7 days to $0.1,2$ and 10

$311 \mu \mathrm{g} / \mathrm{L}{ }^{57}$ In vivo exposures of BDE-47, BDE-100 and BDE-154, also in zebra mussel, 312 caused significant DNA damage up to 5, 11 and 12\% respectively (expressed as \% tail

313 DNA; controls up to 5\%). These values are lower than those reported in this study, but 314 exposure concentrations $(0.1,0.5$ and $1 \mu \mathrm{g} / \mathrm{L})$ and exposure time (4 days) were also 315 lower. ${ }^{58}$ To our knowledge, this is the first study reporting the oxidative capacity of DP 316 in mussels.

318 Mn assay results

319 Mn induced in the negative control were $1.7 \pm 0.6$, while in the positive $\mathrm{B}(\alpha) \mathrm{P}$ control 320 were $2.9 \pm 1 \%$, representing a significant 2 fold increase (ANOVA and post-hoc 321 Tukey's test, $p<0.05)$. Concerning BDE-209, inductions were $1.6 \pm 0.9,1.7 \pm 0.6$ and $3222.7 \pm 0.7$ for 56,100 and $200 \mu \mathrm{g} / \mathrm{L}$ treatments, respectively. The first two concentrations 323 did not cause significant Mn induction compared to controls, but Mn induced by 200 $324 \mu \mathrm{g} / \mathrm{L}$ exposure was significantly higher (ANOVA and post-hoc Tukey's test, $p<0.05$ ). 325 Furthermore, DP caused Mn inductions of $2.0 \pm 0.8,2.0 \pm 1$ and $2.5 \pm 0.8$ at 5.6, 56 and $326100 \mu \mathrm{g} / \mathrm{L}$ treatments, respectively (Figure 4). In this case, BDE-209 and DP showed the 327 same pattern, i.e, Mn induction was only significant at the highest level of exposure. 328 Consequently, DP showed an effect at a lower concentration than BDE-209 (100 and 
$329200 \mu \mathrm{g} / \mathrm{L}$, respectively) which implies that DP is more capable of causing this kind of

330 damage. However, no other studies are available to corroborate this statement.

331 Mn induced by BDE-47, BDE-100 and BDE-154 in zebra mussel were up to 2, 2 and

3322.5 , respectively, but inductions were not significantly different than negative controls. ${ }^{58}$

333 Furthermore, both exposure concentrations $(0.1 \mu \mathrm{g} / \mathrm{L}, 0.5 \mu \mathrm{g} / \mathrm{L}$ and $1 \mu \mathrm{g} / \mathrm{L})$ and

334 exposure time (4 days) were lower than our conditions. This is in agreement with our

335 study, where Mn induction was only found at the highest exposure concentrations. Riva

336 et al. (2007) also reported that BDE-209 can induce DNA strand breaks, but not Mn

337 induction. $^{57}$ Oxidative stress induced by reactive oxygen species (ROS) has been

338 described as one the most plausible mechanism of the toxicity of BDE-209. ${ }^{59}$ As a

339 result, de-bromination of BDE-209 was also considered, since less brominated BDEs

340 present higher oxidative capacity. ${ }^{60}$ In this case, no other brominated congeners were

341 detected (see results below), probably because metabolic/enzymatic capacity of mussels

342 is not as high as in fish. Comet and Mn assay results were not correlated either for BDE-

343209 or DP. This might indicate that these compounds induce primary and repairable

344 lesions rather than permanent ones ${ }^{57}$ since their genotoxic induction can arise through

345 several pathways. However, this topic still requires further work in order to truly

346 understand how these pollutants induce oxidative DNA damage.

348 Chemistry results

349 Water analysis: Concentrations found in water samples taken immediately after dosing

350 were, expressed as mean $\pm \mathrm{SE}(\mu \mathrm{g} / \mathrm{L}): 0.02 \pm 0.01,0.03 \pm 0.02$ and $0.3 \pm 0.2$ in BDE-

351209 treatments $(56,100$ and $200 \mu \mathrm{g} / \mathrm{L}$, respectively). Compared to values found after 23

$352 \mathrm{~h}$ of exposure, concentrations in water decreased 92, 97 and $90 \%$, respectively; in all

353 cases concentrations after $23 \mathrm{~h}$ were lower (One-way ANOVA, $p<0.05$ ). Similarly, 
354 concentrations of DP immediately after dosing were $0.4 \pm 0.3,0.3 \pm 0.2$ and $0.7 \pm 0.5$

$355 \mu \mathrm{g} / \mathrm{L}$ in 5.6, 56 and $100 \mu \mathrm{g} / \mathrm{L}$ treatments, respectively. These concentrations decreased 356 significantly (one-way ANOVA, $p<0.05$ ) up to $77 \%, 79 \%$ and $86 \%$, respectively, after

$35723 \mathrm{~h}$. Levels in control water were below MDL for both compounds in all cases (Figure 358 5A). Concentrations used in this study exceeded the estimated solubility of these 359 compounds $(<1 \mu \mathrm{g} / \mathrm{L}) .{ }^{61}$ However, it has been demonstrated that presence of dissolved 360 organic matter enhances solubility. ${ }^{28}$ BDE-209 and DP rapidly distributes between 361 particulates and mussels, thus concentrations in the aqueous phase are expected to be 362 low.

364 Mussel analysis: Levels of BDE-209 found in the exposed mussels at the end of the 365 treatment were always substantially higher than those in the controls, proving that 366 mussels bioaccumulated BDE-209 through the in vivo exposure (ANOVA and post-hoc

367 Tukey's test, $p<0.05)$. Values were $1.9 \pm 1.3,1.7 \pm 1.1$ and $1.6 \pm 1.2 \mu \mathrm{g} / \mathrm{mussel}$, 368 corresponding to the 56,100 and $200 \mu \mathrm{g} / \mathrm{L}$ exposures. No differences were observed 369 between the three exposures (ANOVA and Tukey's test, $p>0.05$ ). This could be due to 370 BDE-209 de-bromination, but while it has been described in fish ${ }^{62}$ to the best of our 371 knowledge there are no studies in mussels. During the instrumental analysis no other 372 peaks with $\mathrm{m} / \mathrm{z} 79$ and $\mathrm{m} / \mathrm{z} 81$ were observed. Hence, no lower brominated PBDEs or 373 MeO-PBDEs were present in the mussels above the limits of detection. On the other 374 hand, values found in mussels exposed with DP were $4.7 \pm 3.1,8.8 \pm 2.1$ and $21 \pm 9.1$ $375 \mu \mathrm{g} /$ mussel, corresponding to the 5.6, 56 and $100 \mu \mathrm{g} / \mathrm{L}$ treatments, respectively. As for 376 BDE-209, DP values were significantly higher than in the controls in all cases (ANOVA 377 and post-hoc Tukey's test, $p<0.05)$. Furthermore, in the case of DP a concentration 378 dependant increase was found (ANOVA and post-hoc Tukey's test, $p<0.05$ ). These 
379 results show that DP is bioaccumulated by mussels, as has been previously reported. ${ }^{11 \text {, }}$

$380{ }^{29}$ Moreover, the ratio between the anti-isomer and the total DP burden was also 381 evaluated. $F_{\text {anti }}$ is defined as the concentration of anti-DP with respect to the total DP 382 concentration, both lipid-normalized. It has been described as a good indicator of the 383 different behaviour of the two isomers in the environment, since the initial $F_{\text {anti }}$ in the 384 commercial mixture $(\sim 0.7)$ can change when analysing complex organisms such as 385 dolphins. ${ }^{18} \mathrm{~F}_{\text {anti }}$ values found in mussels from the three different exposures $(0.74 \pm 0.02$, $3860.69 \pm 0.03$ and $0.73 \pm 0.02$ for low, medium and high levels, respectively) were similar 387 and significantly lower than values found in the control mussels, which were up to 0.79 $388 \pm 0.04$ (ANOVA and post-hoc Tukey's test, $p<0.05$ ). The commercial mixture of DP 389 used in the exposure was also analysed $(n=3,0.72 \pm 0.02)$. Even if values of the exposed 390 mussels were different than controls, values are still in the range described for 391 commercial DP mixtures. Thus, no syn-DP enrichment was observed, which is in 392 agreement with other studies of DP in mussels. ${ }^{11}$ It has been described that the 393 particulate matter in the gastro-intestinal tract can affect BDE-209 determinations in 394 mussels. ${ }^{63}$ However, since mussels were sampled $24 \mathrm{~h}$ after the last feeding, influence 395 of ingested food in BDE-209 analysis was considered to be minimal, as has been 396 suggested previously. ${ }^{57}$

398 Overall, these data confirm the use of M. galloprovincialis as a suitable biological 399 model for in vivo exposures to FRs. In addition, data for DP represents the first evidence 400 of a genotoxic capacity of this compound in mussels. Both DP and BDE-209 induced 401 significant DNA damage even at the lowest selected concentrations, whereas Mn 402 induction was only significant in the highest doses. Other factors such as the timeframe 403 needed to induce micronuclei require further investigation. In general, further studies 
404 using longer exposure times are recommended. In contrast, the feeding rate was not

405 significantly altered by exposure to either compound.

406

407 Associated content

408 Supporting information: Concentrations in exposure water (Table S1). Concentrations in 409 control mussels (Table S2). Individual concentrations of DP and BDE-209 in mussels

410 (Tables S3 and S4). Individual Mn and \%Tail DNA for each treatment (Tables S5-S7).

411

412 Author information

413 Corresponding author

414 * Phone: +34 934006100 ext 5222; e-mail: eeeqam@cid.csic.es

$415 \quad$ Notes

416 The authors declare no competing financial interest

417

418 Acknowledgements

419 This work has been financially supported by Generalitat de Catalunya (Consolidated 420 Research Groups 2014 SGR 418-Water and Soil Quality Unit) and European Union 421 Seventh Framework programme through the SEA-on-a-CHIP project (FP7-KBBE-

422 OCEAN2013.1 grant agreement no. 614168). Biotage is acknowledged for providing 423 SPE cartridges. Thanks to Lorna Dallas for the help and tips on the laboratory 424 procedures.

425

426 References

427

428 1. Alaee, M.; Arias, P.; Sjödin, A.; Bergman, A., An overview of commercially 429 used brominated flame retardants, their applications, their use patterns in different 
430 countries/regions and possible modes of release. Environment International 2003, 29, 431 (6), 683-689.

432 2. Muñoz-Arnanz, J.; Sáez, M.; Aguirre, J. I.; Hiraldo, F.; Baos, R.; Pacepavicius, 433 G.; Alaee, M.; Jiménez, B., Predominance of BDE-209 and other higher brominated 434 diphenyl ethers in eggs of white stork (Ciconia ciconia) colonies from Spain. 435 Environment International 2011, 37, (3), 572-576.

436 3. Alonso, M. B.; Azevedo, A.; Torres, J. P. M.; Dorneles, P. R.; Eljarrat, E.; 437 Barceló, D.; Lailson-Brito, J.; Malm, O., Anthropogenic (PBDE) and naturally438 produced (MeO-PBDE) brominated compounds in cetaceans - A review. Science of the 439 Total Environment 2014, 481, (1), 619-634.

440 4. Betts, K., Flame retardants are the suspected source of a new compound in the 441

442 environment. Environmental science \& technology 2010, 44, (2), 546-547.

5. Birnbaum, L. S.; Staskal, D. F., Brominated flame retardants: Cause for concern? Environmental Health Perspectives 2004, 112, (1), 9-17.

6. Chen, D.; Hale, R. C., A global review of polybrominated diphenyl ether flame retardant contamination in birds. Environment International 2010, 36, (7), 800-811.

7. Cruz, R.; Cunha, S. C.; Casal, S., Brominated flame retardants and seafood safety: A review. Environment International 2015, 77, 116-131.

8. Linares, V.; Bellés, M.; Domingo, J. L., Human exposure to PBDE and critical evaluation of health hazards. Archives of Toxicology 2015, 89, (3), 335-356.

9. Kierkegaard, A.; Sellström, U.; McLachlan, M. S., Environmental analysis of higher brominated diphenyl ethers and decabromodiphenyl ethane. Journal of Chromatography A 2009, 1216, (3), 364-375.

10. Barón, E.; Mañez, M.; Andreu, A. C.; Sergio, F.; Hiraldo, F.; Eljarrat, E.; Barceló, D., Bioaccumulation and biomagnification of emerging and classical flame retardants in bird eggs of 14 species from Doñana Natural Space and surrounding areas (South-western Spain). Environment International 2014, 68, 118-126.

11. Barón, E.; Rudolph, I.; Chiang, G.; Barra, R.; Eljarrat, E.; Barceló, D., Occurrence and behavior of natural and anthropogenic (emerging and historical) halogenated compounds in marine biota from the Coast of Concepcion (Chile). Science of the Total Environment 2013, 461-462, 258-264.

461 12. Voorspoels, S.; Covaci, A.; Lepom, P.; Escutenaire, S.; Schepens, P., 462 Remarkable Findings Concerning PBDEs in the Terrestrial Top-Predator Red Fox 463 (Vulpes vulpes). Environmental Science \& Technology 2006, 40, (9), 2937-2943.

464 13. Moon, H. B.; Kannan, K.; Lee, S. J.; Choi, M., Polybrominated diphenyl ethers 465 (PBDEs) in sediment and bivalves from Korean coastal waters. Chemosphere 2007, 66, 466 (2), 243-251.

467 14. Noyes, P. D.; Lema, S. C.; Macaulay, L. J.; Douglas, N. K.; Stapleton, H. M., 468 Low Level Exposure to the Flame Retardant BDE-209 Reduces Thyroid Hormone 469 Levels and Disrupts Thyroid Signaling in Fathead Minnows. Environmental science \& 470 technology 2013, 47, (17), 10012-10021.

$471 \quad$ 15. Lee, E.; Kim, T. H.; Choi, J. S.; Nabanata, P.; Kim, N. Y.; Ahn, M. Y.; Jung, K. 472 K.; Kang, I. H.; Kim, T. S.; Kwack, S. J.; Park, K. L.; Kim, S. H.; Kang, T. S.; Lee, J.; 473 Lee, B. M.; Kim, H. S., Evaluation of liver and thyroid toxicity in Sprague-Dawley rats 474 after exposure to polybrominated diphenyl ether BDE-209. Journal of Toxicological 475 Sciences 2010, 35, (4), 535-545.

476 16. Feng, M.; Qu, R.; Li, Y.; Wei, Z.; Wang, Z., Biochemical biomarkers in liver 477 and gill tissues of freshwater fish Carassius auratus following in vivo exposure to 478 hexabromobenzene. Environmental Toxicology 2014, 29, (12), 1460-1470. 
479 17. Garcia-Reyero, N.; Escalon, B. L.; Prats, E.; K. Stanley, J.; Thienpont, B.; 480 Melby, N. L.; Barón, E.; Eljarrat, E.; Barceló, D.; Mestres, J.; Babin, P. J.; Perkins, E. 481 J.; Raldúa, D., Effects of BDE-209 contaminated sediments on zebrafish development 482 and potential implications to human health. Environment International 2014, 63, (0), 483 216-223.

484 18. Xian, Q.; Siddique, S.; Li, T.; Feng, Y. L.; Takser, L.; Zhu, J., Sources and 485 environmental behavior of dechlorane plus - A review. Environment International 2011, 486 37, (7), 1273-1284.

487 19. Sverko, E.; Tomy, G. T.; Reiner, E. J.; Li, Y. F.; McCarry, B. E.; Arnot, J. A.; 488 Law, R. J.; Hites, R. A., Dechlorane plus and related compounds in the environment: A 489 review. Environmental Science and Technology 2011, 45, (12), 5088-5098.

490 20. Covaci, A.; Harrad, S.; Abdallah, M. A. E.; Ali, N.; Law, R. J.; Herzke, D.; de 491 Wit, C. A., Novel brominated flame retardants: A review of their analysis, 492 environmental fate and behaviour. Environment International 2011, 37, (2), 532-556.

493 21. Feo, M. L.; Barón, E.; Eljarrat, E.; Barceló, D., Dechlorane Plus and related 494 compounds in aquatic and terrestrial biota: A review. Analytical and Bioanalytical 495 Chemistry 2012, 404, (9), 2625-2637.

496 22. Dou, J.; Jin, Y.; Li, Y.; Wu, B.; Li, M., Potential genotoxicity and risk 497 assessment of a chlorinated flame retardant, Dechlorane Plus. Chemosphere 2014.

498 23. Zhang, L.; Ji, F.; Li, M.; Cui, Y.; Wu, B., Short-term effects of Dechlorane Plus 499 on the earthworm Eisenia fetida determined by a systems biology approach. Journal of $500 \quad$ Hazardous Materials 2014, 273, 239-246.

501 24. Liang, X.; Li, W.; Martyniuk, C. J.; Zha, J.; Wang, Z.; Cheng, G.; Giesy, J. P., 502 Effects of dechlorane plus on the hepatic proteome of juvenile Chinese sturgeon 503 (Acipenser sinensis). Aquatic Toxicology 2014, 148, 83-91.

504 25. Wu, Z. Y.; Huang, L.; Gao, Y. L.; Guo, Q. H.; Sun, Y. Q., The effects of 505 dechlorane plus on toxicity. In Applied Mechanics and Materials, 2013; Vol. 380-384, 506 pp 4163-4166.

507 26. Jha, A. N., Genotoxicological studies in aquatic organisms: An overview. 508 Mutation Research - Fundamental and Molecular Mechanisms of Mutagenesis 2004, 509 552, (1-2), 1-17.

510 27. Van Beneden, R. J., Molecular analysis of bivalve tumors: Models for 511 environmental/genetic interactions. Environmental Health Perspectives 1994, 102, 512 (SUPPL. 12), 81-83.

513 28. Di, Y.; Schroeder, D. C.; Highfield, A.; Readman, J. W.; Jha, A. N., Tissue514 specific expression of p53 and ras genes in response to the environmental genotoxicant 515 benzo $(\alpha)$ pyrene in marine mussels. Environmental Science and Technology 2011, 45, 516 (20), 8974-8981.

517 29. Jia, H.; Sun, Y.; Liu, X.; Yang, M.; Wang, D.; Qi, H.; Shen, L.; Sverko, E.; 518 Reiner, E. J.; Li, Y. F., Concentration and bioaccumulation of Dechlorane compounds 519 in coastal environment of northern China. Environmental Science and Technology 2011, 520 45, (7), 2613-2618.

521 30. Wu, J. P.; Zhang, Y.; Luo, X. J.; Wang, J.; Chen, S. J.; Guan, Y. T.; Mai, B. X., 522 Isomer-specific bioaccumulation and trophic transfer of dechlorane plus in the 523 freshwater food web from a highly contaminated site, South China. Environmental 524 Science and Technology 2010, 44, (2), 606-611.

525 31. Cristale, J.; García Vázquez, A.; Barata, C.; Lacorte, S., Priority and emerging 526 flame retardants in rivers: Occurrence in water and sediment, Daphnia magna toxicity 527 and risk assessment. Environment International 2013, 59, (0), 232-243. 
528 32. Sutton, R.; Sedlak, M. D.; Yee, D.; Davis, J. A.; Crane, D.; Grace, R.; Arsem, 529 N., Declines in Polybrominated Diphenyl Ether Contamination of San Francisco Bay 530 following Production Phase-Outs and Bans. Environmental science \& technology 2014.

531 33. Brown, R.; Galloway, T.; Lowe, D.; Browne, M.; Dissanayake, A.; Jones, M.; 532 Depledge, M., Differential sensitivity of three marine invertebrates to copper assessed 533 using multiple biomarkers. Aquatic Toxicology 2004, 66, (3), 267-278.

534 34. Canty, M. N.; Hagger, J. A.; Moore, R. T. B.; Cooper, L.; Galloway, T. S., 535 Sublethal impact of short term exposure to the organophosphate pesticide azamethiphos 536 in the marine mollusc Mytilus edulis. Marine Pollution Bulletin 2007, 54, (4), 396-402.

$537 \quad 35 . \quad$ Ostroumov, S. A.; Widdows, J., Inhibition of mussel suspension feeding by 538 surfactants of three classes. Hydrobiologia 2006, 556, (1), 381-386.

539 36. Cheung, V. V.; Depledge, M. H.; Jha, A. N., An evaluation of the relative 540 sensitivity of two marine bivalve mollusc species using the Comet assay. Marine 541 Environmental Research 2006, 62, (SUPPL. 1), S301-S305.

542 37. Jha, A. N.; Dogra, Y.; Turner, A.; Millward, G. E., Impact of low doses of 543 tritium on the marine mussel, Mytilus edulis: Genotoxic effects and tissue-specific 544 bioconcentration. Mutation Research - Genetic Toxicology and Environmental 545 Mutagenesis 2005, 586, (1), 47-57.

546 38. Canty, M. N.; Hutchinson, T. H.; Brown, R. J.; Jones, M. B.; Jha, A. N., Linking 547 genotoxic responses with cytotoxic and behavioural or physiological consequences: 548 Differential sensitivity of echinoderms (Asterias rubens) and marine molluscs (Mytilus 549 edulis). Aquatic Toxicology 2009, 94, (1), 68-76.

550 39. Jha, A. N.; Dogra, Y.; Turner, A.; Millward, G. E., Are low doses of tritium 551 genotoxic to Mytilus edulis? Marine Environmental Research 2006, 62, (SUPPL. 1), 552 S297-S300.

553 40. Kumaravel, T. S.; Jha, A. N., Reliable Comet assay measurements for detecting 554 DNA damage induced by ionising radiation and chemicals. Mutation Research 555 Genetic Toxicology and Environmental Mutagenesis 2006, 605, (1-2), 7-16.

556 41. Ritter, D.; Knebel, J., Genotoxicity testing in vitro - Development of a higher 557 throughput analysis method based on the comet assay. Toxicology in Vitro 2009, 23, (8), $558 \quad 1570-1575$.

559 42. Bolognesi, C.; Fenech, M., Mussel micronucleus cytome assay. Nature 560 protocols 2012, 7, (6), 1125-1137.

561 43. De La Cal, A.; Eljarrat, E.; Barceló, D., Determination of 39 polybrominated 562 diphenyl ether congeners in sediment samples using fast selective pressurized liquid 563 extraction and purification. Journal of Chromatography A 2003, 1021, (1-2), 165-173.

564 44. Eljarrat, E.; Labandeira, A.; Marsh, G.; Raldúa, D.; Barceló, D., 565 Decabrominated diphenyl ether in river fish and sediment samples collected 566 downstream an industrial park. Chemosphere 2007, 69, (8), 1278-1286.

567 45. Barón, E.; Eljarrat, E.; Barceló, D., Analytical method for the determination of 568 halogenated norbornene flame retardants in environmental and biota matrices by gas 569 chromatography coupled to tandem mass spectrometry. Journal of Chromatography A 570 2012, 1248, 154-160.

571 46. Eljarrat, E.; Cal, A.; Barceló, D., Determination of decabromodiphenyl ether in 572 sediments using selective pressurized liquid extraction followed by GC-NCI-MS. 573 Analytical and Bioanalytical Chemistry 2004, 378, (3), 610-614.

574 47. Lyons, B. P.; Stentiford, G. D.; Green, M.; Bignell, J.; Bateman, K.; Feist, S. 575 W.; Goodsir, F.; Reynolds, W. J.; Thain, J. E., DNA adduct analysis and 576 histopathological biomarkers in European flounder (Platichthys flesus) sampled from 
577 UK estuaries. Mutation Research - Fundamental and Molecular Mechanisms of 578 Mutagenesis 2004, 552, (1-2), 177-186.

579 48. Gardner, G. R.; Pruell, R. J.; Malcolm, A. R., Chemical induction of Tumors in 580 oysters by a mixture of aromatic and chlorinated hydrocarbons, amines and metals. 581 Marine Environmental Research 1992, 34, (1-4), 59-63.

582 49. Villela, I. V.; de Oliveira, I. M.; da Silva, J.; Henriques, J. A. P., DNA damage 583 and repair in haemolymph cells of golden mussel (Limnoperna fortunei) exposed to 584 environmental contaminants. Mutation Research/Genetic Toxicology and Environmental Mutagenesis 2006, 605, (1-2), 78-86.

50. Hook, S. E.; Lee, R. F., Genotoxicant induced DNA damage and repair in early and late developmental stages of the grass shrimp Paleomonetes pugio embryo as measured by the comet assay. Aquatic Toxicology 2004, 66, (1), 1-14.

51. Muñoz-Arnanz, J.; Sáez, M.; Hiraldo, F.; Baos, R.; Pacepavicius, G.; Alaee, M.; Jiménez, B., Dechlorane plus and possible degradation products in white stork eggs from Spain. Environment International 2011, 37, (7), 1164-1168.

52. Erratico, C. A.; Moffatt, S. C.; Bandiera, S. M., Comparative oxidative metabolism of BDE-47 and BDE-99 by rat hepatic microsomes. Toxicological Sciences 2011, 123, (1), 37-47.

53. Kelly, B. C.; Ikonomou, M. G.; Blair, J. D.; Gobas, F. A. P. C., Hydroxylated and Methoxylated Polybrominated Diphenyl Ethers in a Canadian Arctic Marine Food Web. Environmental Science \& Technology 2008, 42, (19), 7069-7077.

54. Feo, M. L.; Gross, M. S.; McGarrigle, B. P.; Eljarrat, E.; Barceló, D.; Aga, D. S.; Olson, J. R., Biotransformation of BDE-47 to Potentially Toxic Metabolites Is Predominantly Mediated by Human CYP2B6. Environ Health Perspect 2013, 121, (4), 440-446.

55. Wiseman, S. B.; Wan, Y.; Chang, H.; Zhang, X.; Hecker, M.; Jones, P. D.; Giesy, J. P., Polybrominated diphenyl ethers and their hydroxylated/methoxylated analogs: Environmental sources, metabolic relationships, and relative toxicities. Marine Pollution Bulletin 2011, 63, (5â€“12), 179-188.

56. Wan, Y.; Wiseman, S.; Chang, H.; Zhang, X.; Jones, P. D.; Hecker, M.; Kannan, K.; Tanabe, S.; Hu, J.; Lam, M. H. W.; Giesy, J. P., Origin of hydroxylated brominated diphenyl ethers: Natural compounds or man-made flame retardants? Environmental Science and Technology 2009, 43, (19), 7536-7542.

57. Riva, C.; Binelli, A.; Cogni, D.; Provini, A., Evaluation of DNA damage induced by decabromodiphenyl ether (BDE-209) in hemocytes of Dreissena polymorpha using the comet and micronucleus assays. Environmental and Molecular Mutagenesis 2007, 48, (9), 735-743.

58. Parolini, M.; Binelli, A., Cyto-genotoxic effects induced by three brominated diphenyl ether congeners on the freshwater mussel Dreissena polymorpha. Ecotoxicology and Environmental Safety 2012, 79, 247-255.

59. Regoli, F.; Gorbi, S.; Frenzilli, G.; Nigro, M.; Corsi, I.; Focardi, S.; Winston, G. W., Oxidative stress in ecotoxicology: From the analysis of individual antioxidants to a more integrated approach. Marine Environmental Research 2002, 54, (3-5), 419-423.

60. Labandeira, A.; Eljarrat, E.; Barceló, D., Congener distribution of polybrominated diphenyl ethers in feral carp (Cyprinus carpio) from the Llobregat River, Spain. Environmental Pollution 2007, 146, (1), 188-195.

61. Barón, E.; Eljarrat, E.; Barceló, D., Analysis of halogenated flame retardants by gas chromatography coupled to LRMS, HRMS, MS-MS, and TOF-MS. In Comprehensive Analytical Chemistry, 2013; Vol. 61, pp 373-401. 
626 62. Borgå, K.; Fisk, A. T.; Hoekstra, P. F.; Muir, D. C. G., Biological and chemical 627 factors of importance in the bioaccumulation and trophic transfer of persistent 628 organochlorine contaminants in arctic marine food webs. Environmental Toxicology and 629 Chemistry 2004, 23, (10), 2367-2385.

630 63. Booij, K.; Zegers, B. N.; Boon, J. P., Levels of some polybrominated diphenyl 631 ether (PBDE) flame retardants along the Dutch coast as derived from their accumulation 632 in SPMDs and blue mussels (Mytilus edulis). Chemosphere 2002, 46, (5), 683-688.

633

634 
635 Table 1: Recoveries (\%), RSD (\%), MDL and MDL of BDE-209 and DP in water $636(\mathrm{ng} / \mathrm{mL})$ and mussel (pg/g lw)

\begin{tabular}{ccccc|cccc} 
Compound & \multicolumn{4}{c|}{ Water } & \multicolumn{5}{c}{ Mussel } \\
\hline & R & RSD & MLOD & MLOQ & R & RSD & MLOD & MLOQ \\
\hline BDE-209 & 75 & 11 & 0.40 & 1.30 & 68 & 6 & 200 & 330 \\
syn-DP & 67 & 8 & 0.60 & 2.00 & 85 & 7 & 5.50 & 18.3 \\
anti-DP & 73 & 12 & 0.10 & 0.30 & 88 & 5 & 4.30 & 14.3 \\
\hline
\end{tabular}

637 


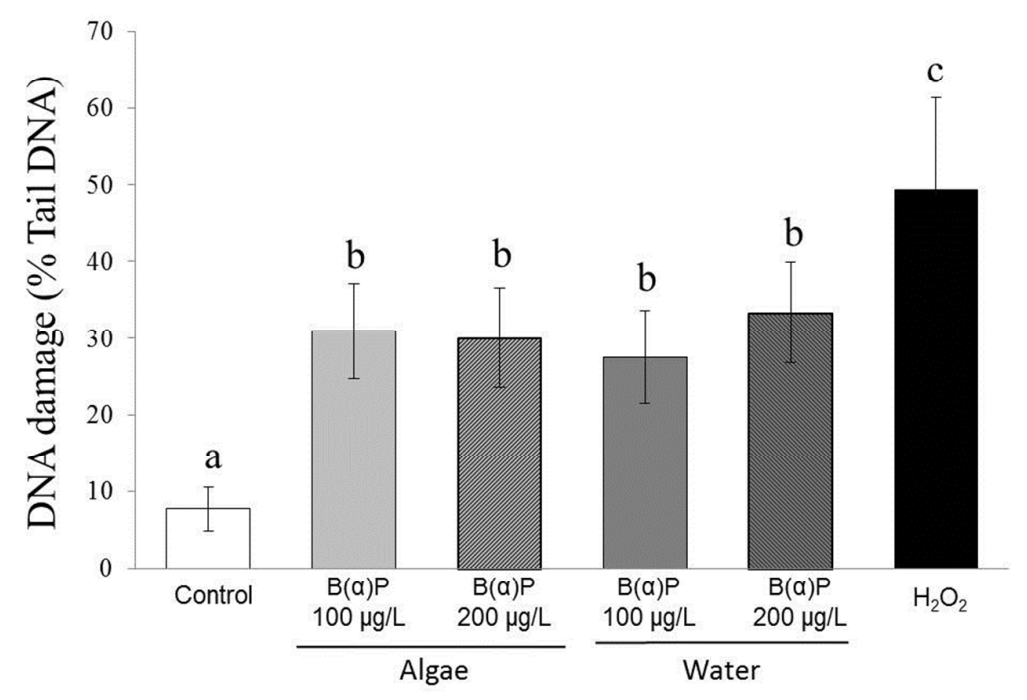

639 Figure 1: DNA damage (mean $\pm \mathrm{SD} ; \mathrm{n}=6$ per treatment) in benzo $(\alpha)$ pyrene-exposed 640 mussels. Treatments with the same letter are not significantly different; where 641 significant differences occur between treatments, $p<0.001$.

642 


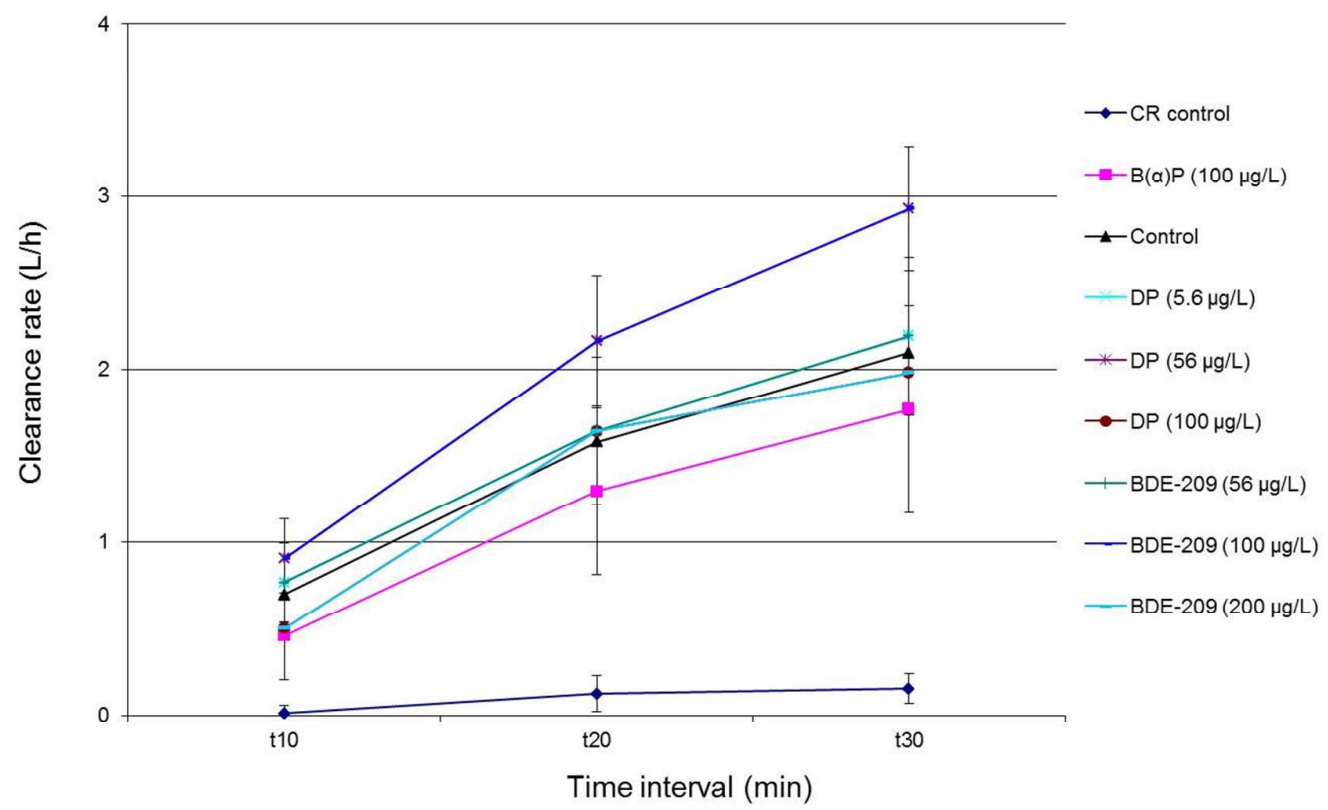

643

644 Figure 2: Clearance rate $(\mathrm{L} / \mathrm{h})$ of the different treatments. Error bars represent SD. $\mathrm{n}=7$

$645 \mathrm{CR}$ control $=$ seawater. Control $=$ control mussel exposed to acetone $(0.05 \%, \mathrm{v} / \mathrm{v})$ 

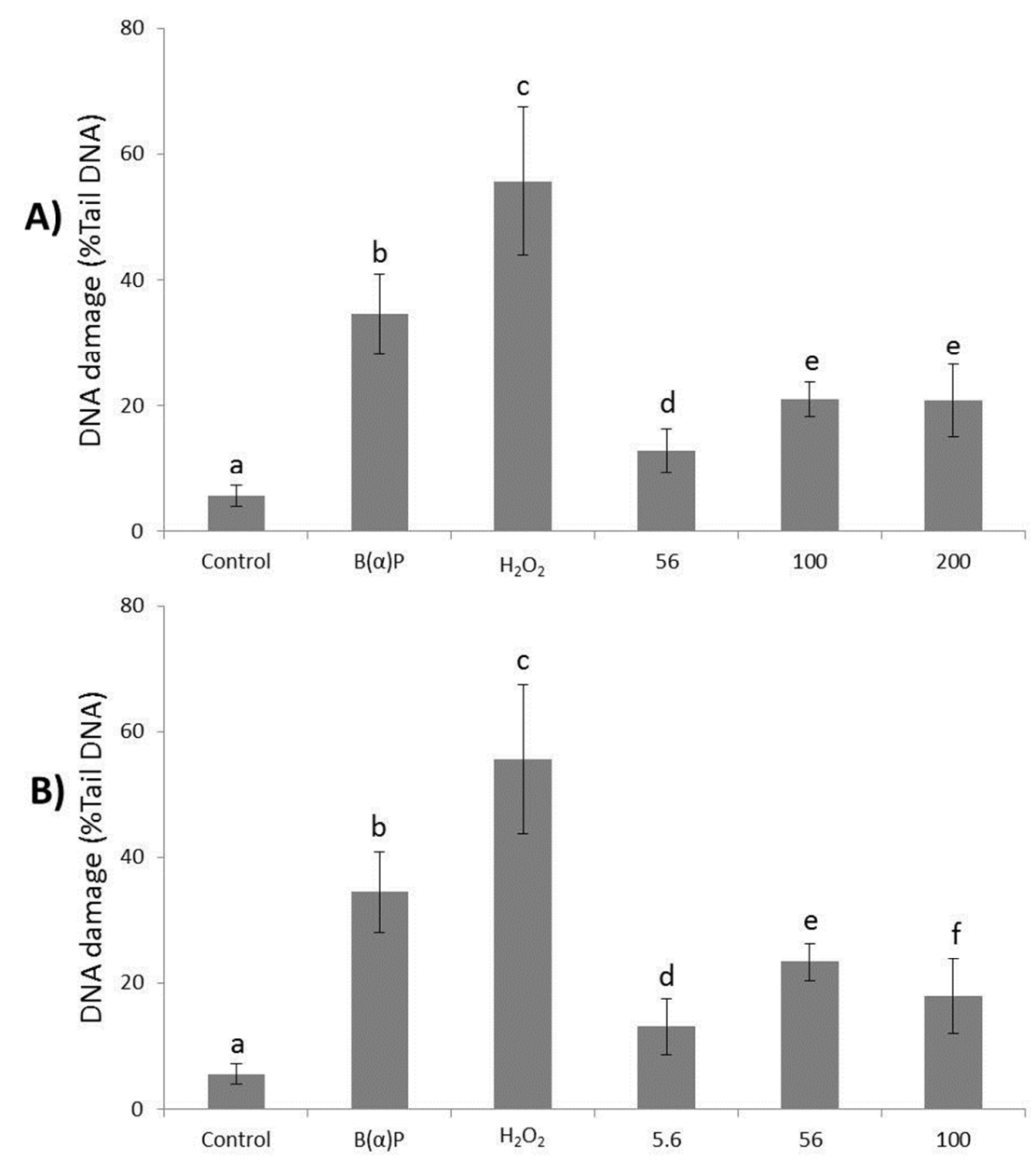

646

647 Figure 3: Induction of DNA strand breaks (represented as \% Tail DNA \pm SD) in 648 Mytilus galloprovincialis haemolymph after 6 days of exposure to FRs compared to 649 control mussels, exposure to $\mathrm{B}(\alpha) \mathrm{P}(100 \mu \mathrm{g} / \mathrm{L})$ and $\mathrm{H}_{2} \mathrm{O}_{2}(1 \mathrm{mM}$, in vitro $)$. A) BDE-209.

650 B) DP. Treatments with the same letter are not significantly different; where significant 651 differences occur between treatments, $p<0.05$.

652 


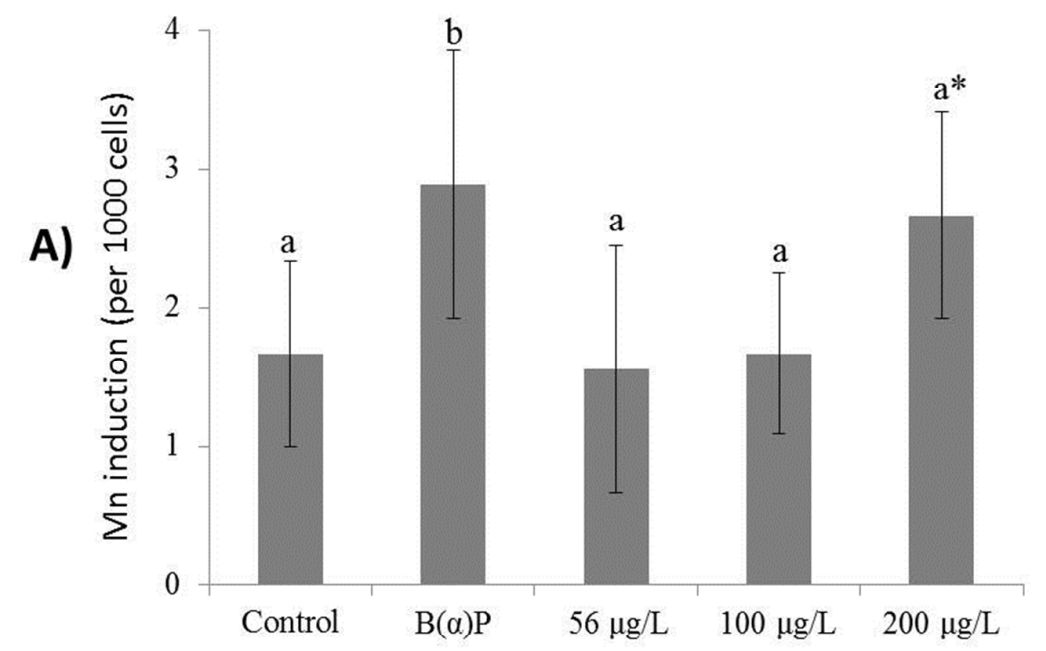

653

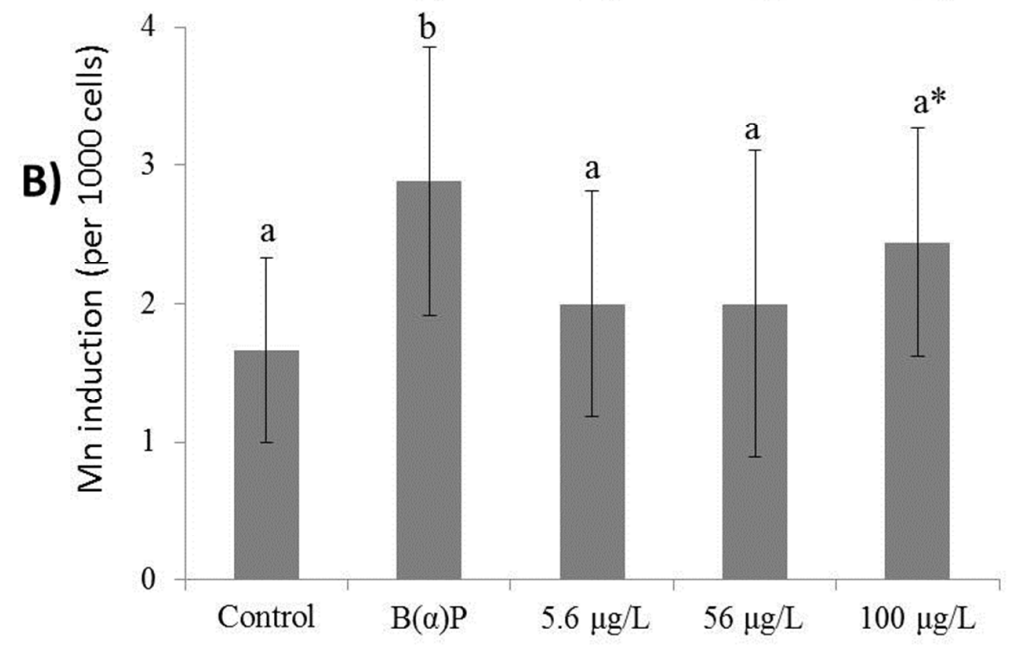

654 Figure 4: $\mathrm{Mn}$ induction (represented as mean $\pm \mathrm{SD}$ ) in Mytilus galloprovincialis 655 haemolymph after 6 days of exposure to FRs compared to control mussels and exposure 656 to $\mathrm{B}(\alpha) \mathrm{P}(100 \mu \mathrm{g} / \mathrm{L})$. A) BDE-209. B) DP. Treatments with the same letter are not 657 significantly different; where significant differences occur between treatments, $p<0.05$. 


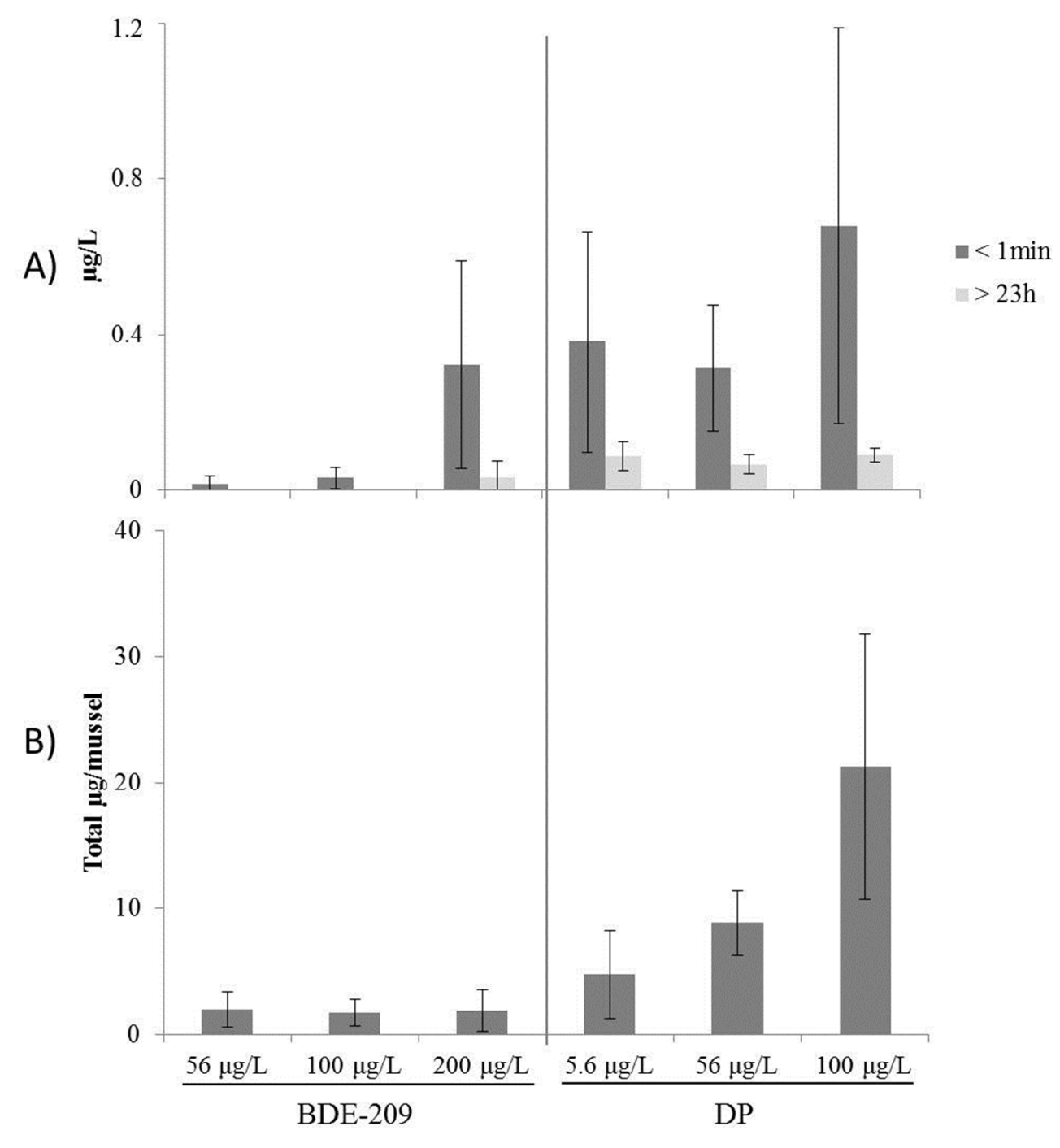

658

659 Figure 5: A) Concentrations of BDE-209 and DP found in water samples corresponding 660 to the exposures ( $\mathrm{n}=3$ per treatment) after dosing and immediately before the water 661 change. Concentrations in control samples were below the MDL in both cases. B) 662 Levels of BDE-209 and DP found in exposed mussels ( $n=7)$. Control levels were $0.04 \pm$ $6630.02 \mu \mathrm{g}$ for BDE-209 and $0.11 \pm 0.06 \mu \mathrm{g}$ for DP. 